\title{
Body weight and blood chemistry of wild coatis that feed on discarded human food
}

\author{
Renata Barcelos Repoles ${ }^{1}$ (D) Clarice Silva Cesario ${ }^{1}$ (D) Edilberto Nobrega Martinez ${ }^{1}$ \\ Waldomiro de Paula Lopes ${ }^{2}$ (D) Delma Henriques Rodrigues ${ }^{1}$ (D) João Paulo Carvalho ${ }^{1}$ \\ Viviane Silva Oliveira ${ }^{3}$ Alessandro Brinati ${ }^{1}$ Giovana França Bispo da Gama ${ }^{4}$ \\ Nadja Simbera Hemetrio ${ }^{5}$ It Ita Oliveira e Silva ${ }^{4}$ Vanner Boere ${ }^{4^{*}}$ (D)
}

\author{
${ }^{1}$ Universidade Federal de Viçosa (UFV), Viçosa, MG, Brasil. \\ ${ }^{2}$ Parque Nacional do Caparaó, Instituto Chico Mendes de Conservação da Biodiversidade (ICMBio), Alto Caparaó, MG, Brasil. \\ ${ }^{3}$ Universidade Estadual de Minas Gerais (UEMG), Carangola, MG, Brasil. \\ ${ }^{4}$ Universidade Federal do Sul da Bahia (UFSB), Itabuna, BA, Brasil. E-mail: vannerboere@uol.com.br. "Correponding author. \\ ${ }^{5}$ Projeto Quatis, Belo Horizonte, MG, Brasil.
}

\begin{abstract}
The coati (Nasua nasua, Linnaeus 1766) is a generalist species, feeding on often-discarded human food in dumpsters around ecological tourism sites. We investigated the body weight and some blood chemistry variables related to the diet of wild coatis from three parks: Parque Municipal das Mangabeiras (PM), Parque Nacional do Caparaó (PNC) e Estação Ecológica Água Limpa (EEAL). We tested the plasma of 53 coatis for high-density lipoprotein (HDL), alanine transaminase (ALT), aspartate transaminase (AST), gamma-glutamyl transferase (GGT), cholesterol (Chol), triglycerides (Trig), and alkaline phosphatase (ALP). Male and female adults did not significantly differ on the weight $(P>0.05)$ and blood chemistry indexes $(P>0.05)$. The adult coatis of the PM were heavier than the adult coatis of the other two parks. There were significant differences in HDL $(P<0.04)$, AST $(P<0.001), A L T(P<0.001)$, and $G G T(P<0.001)$ between adults of the three parks. Only ALT and ALP were significantly different $(P<0.05)$ among the young coatis. The results suggested the coatis of the three parks have different health status. The consumption of discarded human food seems to affect body weight of the PM coatis. The coatis from $P N C$ and EEAL had blood chemistry profiles suggestive of liver disorder. We recommend carrying on environmental education programs to visitors and additional clinical investigations on coatis from these parks.

Key words: garbage, Nasua nasua, physiology, serum chemistry, tourists.
\end{abstract}

Peso corporal e química sanguínea de quatis selvagens que consomem alimento humano descartado

RESUMO: O quati (Nasua nasua, Linnaeus 1766) é uma espécie generalista que alimenta-se de comida humana frequentemente descartada em lixeiras ao redor de locais de turismo ecológico. Investigou-se o peso corporal e algumas variáveis da química sanguínea relacionadas à dieta de quatis selvagens de três parques: Parque Municipal das Mangabeiras (PM), Parque Nacional do Caparaó (PNC) e Estação Ecológica Água Limpa (EEAL). Testou-se o plasma de 75 quatis para lipoprotequatis sitaabeiras (PM), Parque Nacional do Caparaó (PNC) aspartato transaminase (AST), gama-glutamil transferase (GGT), colesterol (Chol), triglicerideos (Trig) e fosfatase alcalina (ALP). Machos e fêmeas adultos não diferiram significativamente quanto a peso $(P>0,05)$ e índices de química sanguínea $(P>0,05)$. Os quatis adultos do $P M$ foram mais pesados em relação aos quatis adultos dos outros dois parques. Houve diferenças significativas em HDL $(P<0,04)$, AST $(P$ $<0,001)$, ALT $(P<0,001)$ e GGT $(P<0,001)$ entre os adultos dos três parques. Apenas ALT e ALP foram significativamente diferentes $(P$ $<0,05)$ entre os quatis jovens. Os resultados sugerem que os quatis dos três parques apresentam diferentes estados de saúde. $O$ consumo de alimentos humanos descartados parece afetar o peso corporal dos quatis do PM. Os quatis do PNC e da EEAL apresentaram perfis químicos sanguíneos sugestivos de doença hepática. Recomendamos a realização de programas de educação ambiental aos visitantes e investigações clínicas adicionais nos quatis desses parques.

Palavras-chave: fisiologia, turistas, lixo, Nasua nasua, química do soro.

\section{INTRODUCTION}

Food supplementation and the opportunistic foraging of the waste from human activity have caused serious problems in the digestive tract of wild animals, resulting in sickness and death
(MURRAY et al., 2016). Most of these foods have a high caloric level and their intake can increase blood glucose and cholesterol (BENATAR et al., 2013), as well as lead to the accidental consumption of toxins, pesticides and plastics (BRADLEY; ALTIZER, 2006). The liver is one of the organs most affected by 
this, and plasma indexes of hepatocytes metabolites can evaluate its function (GREEN; FLAMM, 2002).

Tourism activities in parks have increased in recent decades, benefiting the economy and human welfare. At the same time, this have caused changes in the behavior and physiology of wild animals (RIEKEHR Jr. et al., 2017; SEMENIUK et al., 2007). Effects of waste intake generated by tourists on wildlife metabolism are scarcely explored; although, there is a consensus that the changes are more harmful than beneficial (MURRAY et al., 2016). In sum, tourism in protected areas have occurred at a higher speed than the research on its impact on fauna. Intensive exploitation of processed foods by wild animals causes an imbalance in the food chain (MURRAY et al., 2016; FERREIRA et al., 2013). For instance, one study reported that coatis fed by tourists with processed foods, rich in carbohydrates and fats, had higher blood concentration of glucose, triglycerides and total protein compared to a control group and the reference values (RIEKEHR Jr. et al., 2017). The typical food consumed in Brazil constitutes $69.5 \%$ of natural or minimally processed foods, $9 \%$ of processed foods, and $21.5 \%$ of ultra-processed foods (LOUZADA et al., 2015). Ultra-processed foods such as snacks, canned food, sauces and cookies contain high levels of fat which, if consumed in excess, cause metabolic disorders (LOUZADA et al., 2015).

Studies about the consumption of human processed foods effects on wild animals are generally indirect, observational and relational. Direct investigations, with control groups and controlled volumes of food for experimental purposes, have operational limitations and they are, in most cases, ethically unfeasible. It is known the coatis explore human food disposed by visitors in parks (RIEKEHR Jr. et al., 2017; FERREIRA et al., 2013). Therefore, we investigated the impact of this behavior on weight and some metabolic indexes of coatis from three protected areas where they can exploit the waste and food given by visitors.

\section{MATERIALS AND METHODS}

We conducted the study in three parks on Atlantic Forest biome, Brazil, where the coati contact with humans is in different degrees of intensity: Mangabeiras Park (Parque das Mangabeiras - PM), Caparaó National Park (Parque Nacional do Caparaó - PNC) and Clean Water Ecological Station (Estação Ecológica Água Limpa - EEAL) (Figure 1). The PM is located in the southern of Belo Horizonte (19 $56^{\circ}$ $\mathrm{S}$ and $\left.43^{\circ} 54^{\prime} \mathrm{W}\right)$, Minas Gerais State, a region characterized by an intensive iron miner exploration. The estimated influx of visitors is about 30000 per month (ROCHA; ABJAUD, 2012) including students, families, couples and friend groups. It has many paved trials and the recreational activities, structures for rest, leisure, toilets and food court are concentrated in the core area. The PNC is on the border of Minas Gerais and Espírito Santo States (between $20^{\circ} 22^{\prime}$ and $20^{\circ} 37^{\prime} \mathrm{S}$, and $41^{\circ} 48^{\prime}$ ' and $41^{\circ} 57^{\prime}$ $\mathrm{W})$, with an area of 25174.84 ha and the third-highest point in the country, at $2892 \mathrm{~m}$ of altitude (IEF, 2020). It receives 23000 visitors each year with a profile of concern for environmental conservation. It has four camping areas with dumpsters, toilets, dishwashers and tables. The EEAL is in the municipality of Cataguases $\left(21^{\circ} 22^{\prime} \mathrm{S}, 42^{\circ} 42^{\prime} \mathrm{W}\right)$, Zona da Mata of Minas Gerais, with an altitude of $282 \mathrm{~m}$. It is visited by an estimated 900 people per month (MACHADO; SOUZA, 2008), only for restricted educational activities in a concentrated area $\left(1600 \mathrm{~m}^{2}\right)$, or to carry out sporadic research (IEF, 2020).

We captured the coatis in Tomahawk-like traps using bananas as bait, between July 2012 and July 2013. Veterinarians anesthetized the captured animals with ketamine $(10 \mathrm{mg} / \mathrm{kg})$ and xylazine $(0.5 \mathrm{mg} / \mathrm{kg})$, intramuscularly, to perform physical examination, sample collection, biometry, weighing, sexing, aging, identification (microchip and ear tag), assessment of oral health and anesthetic monitoring. We defined age class based on biometrics, tooth eruption, wear and staining, reproductive status and weight (OLIFIERS et al., 2010).

We collected $2 \mathrm{ml}$ of blood by femoral or jugular venipuncture with plastic tubes (BD Vacutainer $^{\circledR}$ ) and centrifuged at $700 \mathrm{~g}$ for $15 \mathrm{~min}$, soon after collection. The parameters analyzed were high-density lipoprotein (HDL), alanine transaminase (ALT), aspartate transaminase (AST), gammaglutamyltransferase (GGT), cholesterol (Chol), triglycerides (Trig) and alkaline phosphatase (ALP). The laboratorial technics to cholesterol, triglycerides and HDL was colorimetric enzymatic (Roche); and to AST, ALT, GGT and ALP was kinetic colorimetric essay (BioclinQuibasa). The device used was the Cobas Mira Plus.

The serum essays (Table 1) were carried out in the Veterinarian Clinics Laboratory of the Health Division of the Federal University of Viçosa, MG, Brazil. We defined the anthropic impact degree based on tourist visitation intensity, reflected in the availability of human origin foods on the dumpsters or directly provided. We collected some behavioral data using direct opportunistic observations. We 


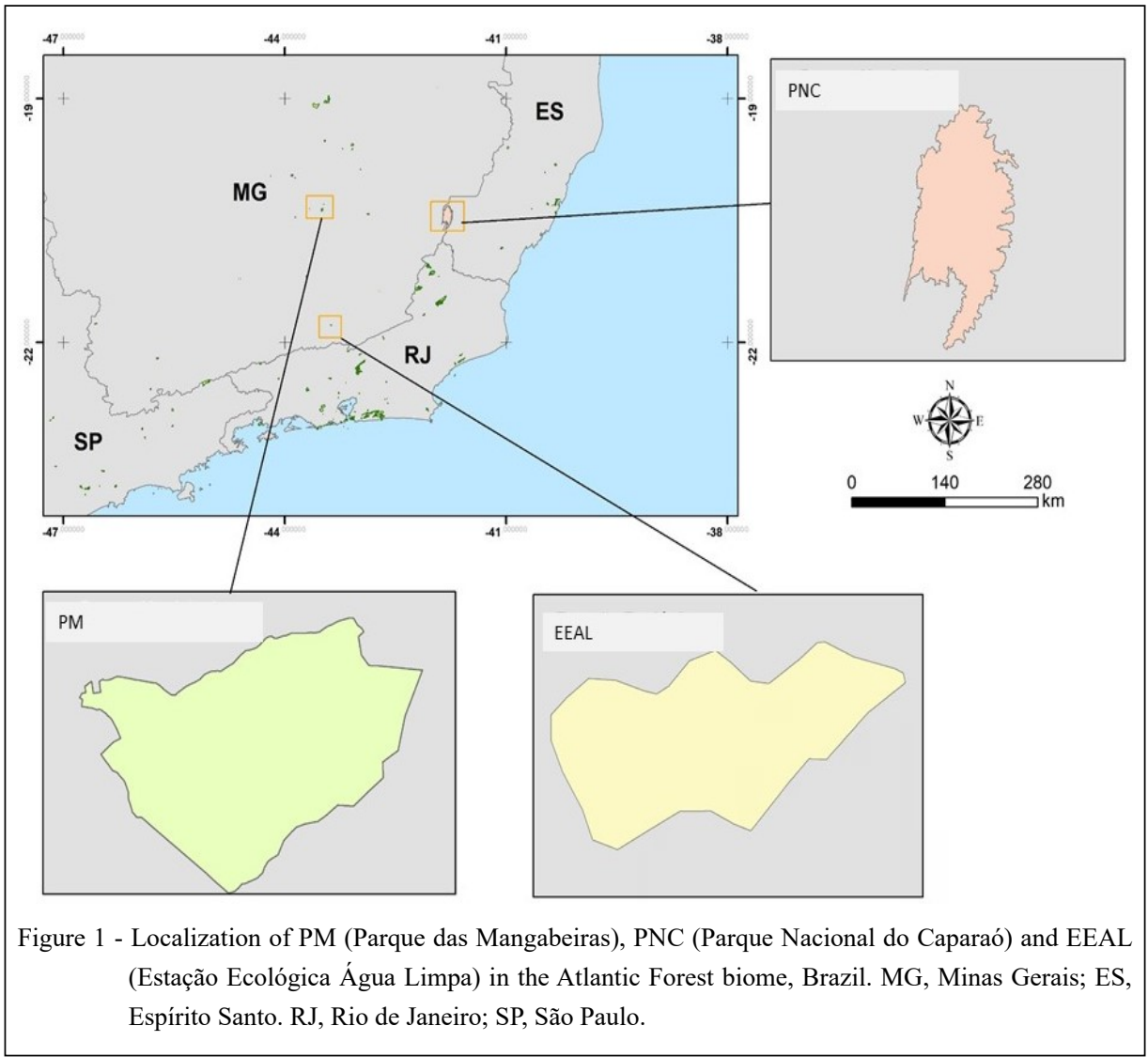

also conducted informal interviews with park staff and surrounding residents in order to understand the natural history of coatis' populations.

We calculated the averages, medians and standard deviation from the data set of each physiological index and weight per category (adult males, adult females and young) of each park. We tested the weight and blood chemistry indexes normality distribution using the Shapiro-Wilk test. As the data did not present normal distribution $(\mathrm{P}<0.01)$, we used nonparametric statistical tests. To compare weight and blood chemistry concentrations between adult males and females, we applied the Mann-Whitney test for two independent samples, regardless of the study area, and Kruskal-Wallis test for differences between more than two independent samples. Due to the small sample of young coatis, we used Mann-Whitney test for comparison between two independent samples. We performed all analyses using the Statistical Package for Social Sciences (SPSS for Windows, version 13.0, SPSS Inc. Chicago, IL, USA) with significance level $<0.05$.

We collected some qualitative data based on informal interviews with park employees and residents of the region, addressing the behavior of coatis. Our team made several behavioral observations ad libitum of the coatis. From the set of information from informal conversations and accumulated behavioral data, we can outline a better scenario for interpreting our quantitative data.

\section{RESULTS}

We captured 31 coatis in the PM, 36 in the PNC, and eight in the EEAL, totaling 75 individuals ( 31 female and 24 male). Six of the PM coatis and 14 of the PNC coatis were young (11 female and 9 male). Young coatis did not fall into the traps at the EEAL. Twenty-two samples did not have enough blood volume to be analyzed in the chemical tests. Therefore, we analyzed 53 samples (33 adults and 20 young). Table 1 presents means and standard errors of weight and blood chemical parameters from coatis of all parks and age classes. We did not find statistical differences between adult male $(n=11)$ and female $(n=22)$ for any of the parameters analyzed (Table 2 ). 
Table 1 - Weight and blood chemical parameters (mean \pm standard error) of adults $(\mathrm{n}=33)$ and young $(\mathrm{n}=20)$ coatis $($ Nasua nasua). HDL, high-density lipoprotein; AST, aspartate transaminase; ALT, alanine transaminase; GGT, gamma-glutamyltransferase; ALP, alkaline phosphatase.

\begin{tabular}{|c|c|c|c|c|c|}
\hline \multirow{2}{*}{ Index } & \multicolumn{5}{|c|}{ 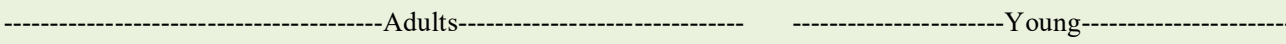 } \\
\hline & PM & PNC & EEAL & PM & $\mathrm{PNC}$ \\
\hline Weight $(\mathrm{Kg})$ & $4.72 \pm 1.03$ & $3.28 \pm 0.46$ & $3.12 \pm 0.35$ & $2 \pm 0$ & $2.2 \pm 0.62$ \\
\hline Cholesterol (mg/dl) & $177.19 \pm 31.77$ & $180.72 \pm 45.11$ & $184 \pm 33.62$ & $137.5 \pm 28.92$ & $162.07 \pm 41.84$ \\
\hline Triglycerides (mg/dl) & $28.94 \pm 16.54$ & $20.18 \pm 5.15$ & $26.75 \pm 13.57$ & $27.83 \pm 5.53$ & $24.64 \pm 7.61$ \\
\hline HDL (mg/dl) & $114.12 \pm 67.39$ & $92 \pm 21.9$ & $100.88 \pm 14.31$ & $91.83 \pm 12.34$ & $89.14 \pm 18.94$ \\
\hline AST (U/1) & $180.56 \pm 67.39$ & $275.82 \pm 114.53$ & $461 \pm 189.16$ & $232.33 \pm 76.01$ & $371.57 \pm 138.77$ \\
\hline ALT (U/1) & $76.88 \pm 19.78$ & $103.73 \pm 37$ & $135.75 \pm 50.52$ & $101.17 \pm 22.15$ & $108.29 \pm 47$ \\
\hline GGT (U/l) & $7.19 \pm 4.53$ & $16.18 \pm 7.92$ & $6.71 \pm 4.03$ & $10.67 \pm 3.99$ & $14.14 \pm 6.21$ \\
\hline ALP (U/1) & $23.94 \pm 10.07$ & $23.27 \pm 13.63$ & $22.62 \pm 5.7$ & $23.84 \pm 8.38$ & $51.85 \pm 24.01$ \\
\hline
\end{tabular}

We reported differences in the mean weight between the adult coatis of the three parks (KruskalWallis, G.L. $=2, \chi 2=22.68, \mathrm{P}<0.001$ ) (Figure $2 \mathrm{~A})$. The adult coatis of the PM had a significantly higher weight than those of the PNC and the EEAL (Figure 2A). We observed significant differences in HDL (Kruskal-Wallis, G.L. $=2, \chi 2=6.81, \mathrm{P}<0.04$ ) (Figure 2B), AST (Kruskal-Wallis, G.L. $=2, \chi 2=$ 15.55, $\mathrm{P}<0.001$ ) (Figure $2 \mathrm{C}$ ), ALT (Kruskal-Wallis, G.L. $=2, \chi 2=14.30, P<0.001$ ), and GGT (KruskalWallis, G.L. $=2, \chi 2=12,62, \mathrm{P}<0.001$ ) (Figure 2D), between the adult coatis of the three parks. However, there were no statistical differences in Chol (Kruskal-Wallis, G.L. $=2, \chi 2=0.23, \mathrm{P}=0.89$ ), Trig (Kruskal-Wallis, G.L. $=2, \chi 2=4.63, \mathrm{P}=0.10$ ) and ALP (Kruskal-Wallis, G.L. $=2, \chi 2=0.74, \mathrm{P}<0.70$ ) among the adult coatis of the three parks.

The adult coatis of PM had significantly higher plasma concentrations of HDL than the adult coatis of PNC but did not differ from those of the EEAL, which, in turn, did not differ statistically from the adult coatis of the PNC. AST levels were significantly different between the coatis of EEAL and those of the other two parks. However, AST concentrations of the adult coatis of the PM and the PNC were not differentiated. The adult coatis of the EEAL had substantially higher ALT concentrations than the PM coatis, while the adult coatis of the PNC did not differ statistically from those of the PM, and neither were in relation to the EEAL coatis. The GGT concentration of the PNC adult coatis was substantially higher in relation to those of the PM and the EEAL. There were no differences in the GGT concentration between the adult coatis of the PM and the EEAL.
Since no young coatis were captured in the EEAL, we compared the results from those captured in the PM and the PNC. The young coatis of the PNC have significantly higher concentrations of ALT (Mann-Whitney, $\mathrm{U}=1.0, \mathrm{P}<0.05$ ) and ALP (Mann-Whitney, $\mathrm{U}=7.0, \mathrm{P}<0.05$ ) than those of the PM (Figure 3 ). The young coatis of the PM and the PNC did not differ statistically in weight (MannWhitney, $\mathrm{U}=0.0, \mathrm{P}=0.25$ ), Chol (Mann-Whitney, $\mathrm{U}=5.0, \mathrm{P}=0.16$ ), Trig (Mann-Whitney, $\mathrm{U}=6.5, \mathrm{P}$ $=0.20$ ), HDL (Mann-Whitney, $\mathrm{U}=2.0, \mathrm{P}=0.41$ ), AST (Mann-Whitney, $\mathrm{U}=4.5, \mathrm{P}=0.53$ ), and GGT (Mann-Whitney, $\mathrm{U}=7.5, \mathrm{P}=0.23$ ).

\section{DISCUSSION}

Determining health status of wild animals is complex because of technical, operational methodological and ethical difficulties. In addition, there is a large gap about reference values, used to interpret results and to guide comparisons between wild animal populations (WHILDE et al., 2017). This is true even for conventional tests, like blood chemical profile. It is important to consider that prior knowledge of health history, diverse diagnostic tests and behavior observation are extremely important on diagnose, not always possible in short-term and financially limited researches. The wide variation in environment, diet and capture stress also influenced the results of some biological markers (NABI et al., 2017; TOPAL et al., 2010). The lack of robust data for many species as well as the fact that most of the existent come from captive individuals, increase the limitations (WHILDE et al., 2017). Life history, such 
Table 2 - Weight and blood chemical parameters (mean \pm standard error) of adult male $(\mathrm{n}=11)$ and female $(\mathrm{n}=22)$ coatis $($ Nasua nasua). HDL, high-density lipoprotein; AST, aspartate transaminase; ALT, alanine transaminase; GGT, gammaglutamyltransferase; ALP, alkaline phosphatase.

\begin{tabular}{lcccc}
\hline Index & Male & Female & U & $P$ \\
\hline Weight (Kg) & $4.36 \pm 1.53$ & $3.53 \pm 0.61$ & 86 & 0.18 \\
Cholesterol (mg/dl) & $172.09 \pm 35.43$ & $188.32 \pm 33.23$ & 99 & 0.40 \\
Triglycerides (mg/dl) & $26.82 \pm 11.11$ & $25.27 \pm 14.96$ & 97 & 0.35 \\
HDL (mg/dl) & $104.82 \pm 23.75$ & $104.86 \pm 18.16$ & 97 & 105 \\
AST (U/l) & $230.73 \pm 84.2$ & $297.64 \pm 187.11$ & 120.5 & 76 \\
ALT (U/l) & $96.91 \pm 24.54$ & $102.09 \pm 47.82$ & 0.54 \\
GGT (U/l) & $8.82 \pm 8.69$ & $11.29 \pm 6.55$ & 0.11 \\
ALP (U/l) & $28 \pm 12.32$ & $22.00 \pm 9.48$ & 0.12 & 81 \\
\hline
\end{tabular}

as sex and age, has also been taken into account in health status interpretation, since such organisms are subject to different physiological and external pressures. Even with the various examples in literature that point out the effect of sex and age (SATO et al., 2005; MIKNIENE et al., 2013; XIE et al., 2013), these differences are not always evident. We did not find significant variation between adult male and female, which corroborates with a study with coatis living in captivity (RODRIGUES et al., 1996). However, we reported significant differences in chemical profile between adults and young coatis, suggesting their health are not the same in PM, PNC and EEAL.

The adult coatis from PM were heavier than the ones from the other two parks (Figure 2A). The higher number of visitors during all periods of the year implies on more availability of food discarded or provided by visitors. There are plenty of garbage devices in the PM and it was common to observe different groups of coatis exploring them every day, which we confirmed with park officers and surrounding residents through informal interviews. This phenomenon and its impacts are documented worldwide involving several species that approach humans (MARÉCHAL et al., 2016; MURRAY et al., 2016; NEWSOME; RODGER, 2013; ORAMS, 2002). Supply of food provided by humans is a major cause for greater body size among wild animals (MARÉCHAL et al., 2016), including coatis, heavier when provisioned with human food comparing to those without access (RIEKEHR Jr et al., 2017). Considering this and our observations, we strongly suggested that the higher weight of the PM coatis is an effect of this great opportunities and abundant consumption of very high caloric food at low energy cost. In the PNC, in addition to the smaller number of tourists and concentration of tourism in dry seasons, there are three stations for the use of visitors, $4 \mathrm{~km}$ and $1200 \mathrm{~m}$ of altitude apart each other. Therefore, the chances of obtaining food are lower, they depend more on displacements between feeding sites, and the energy expenditure is higher. The EEAL adult coatis have no opportunities to eat ultra-processed foods, since visits to environmental education are guided and scheduled, food consumption inside is discouraged and well monitored. This results in a diet majority based on the exploitation of natural resources.

Garbage consume can be harmful to wild animals, especially the non-digestible residues (MACHOVSKY-CAPUSKA et al., 2019). Garbage residues represented $7.1 \%$ of fecal content of coatis from an urban park in Juiz de Fora municipality (FERREIRA et al., 2013), 6.4\% from PM and 1\% from PNC coatis (RODRIGUES et al., 2021). Although, pieces of garbage can have traumatic effects on the mouth, we did not find oral injuries in the coatis. However, the damage caused by the consumption of garbage does not reflect only on weight increase or wounds on the digestive tract. Since higher weight is a favorable sign of health in wild animals, unlike captive animals (DIERENFELD et al., 1997), only the physiological parameters associated with weight can clarify if wild coatis with higher weight are healthier. The blood chemistry variables seem less affected by human food ingested, since PM coatis did not presented, based on the parameters we tested, any alterations suggestive of sickness. On the contrary, the 


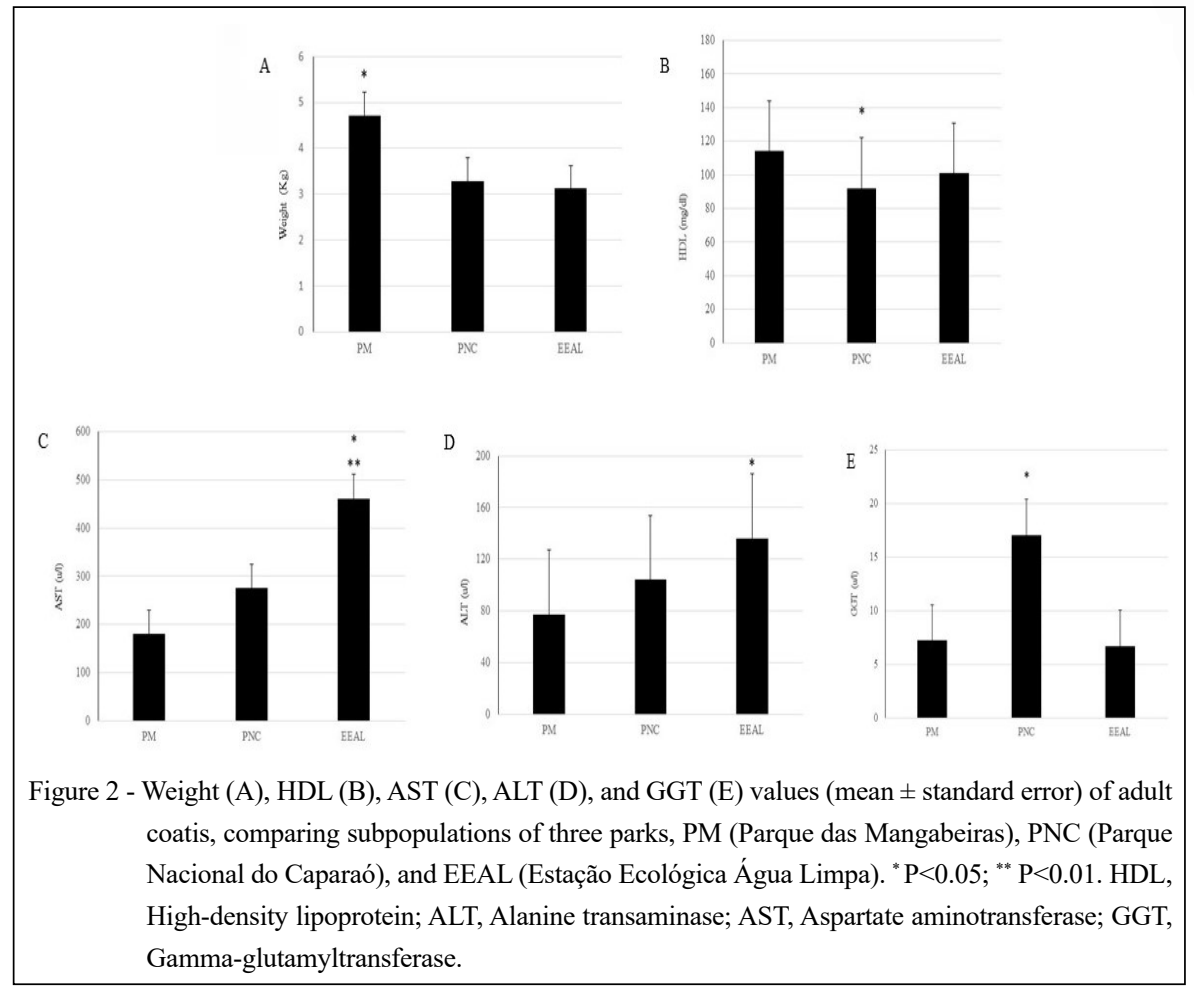

high value of HDL in the adult coatis from PM may be protective of vascular degeneration. An increase in serum HDL levels in experimental animals and humans can prevent the progression of atherosclerotic plaque and promote its regression (JOHNSEN et al., 2005). Therefore, if this holds validity for coatis, individuals of the PM are more likely to be protected in this aspect than the PNC's.

In PNC and EEAL where there are less visitors, the blood chemistry profile of the coatis is suggestive of liver disorders, but causes other than human food ingestion is likely. Moderate elevations of hepatic transaminases are relatively common in mammals and can be found in routine blood tests in healthy individuals due to capture stress (SIEGEL\& WALTON, 2020]. The three groups of coatis were subjected to similar capture and management conditions for venipuncture in all three parks. Due to the short venipuncture time, it is unlikely that the capture stress modified the enzymatic patterns of the EEAL coatis in relation to the adult individuals of the $\mathrm{PM}$ and the PNC.

Hepatic transaminases are enzymatic markers of hepatic diseases such as viral hepatitis (GREEN\& FLAMM, 2002). The EEAL coatis appear to be affected by a liver impairment since they have higher plasma concentrations of ALT and AST in comparison with the adult individuals of the PM. Coatis of the PNC have intermediate levels of ALT and AST compared to those of the PM and the EEAL, but the differences are not statistically significant.

In our review of the scientific literature of the main databases, there were no reports of alterations of AST and ALT in wild coatis. The lack of information on the parameters in wild coatis and the epidemiological data of the EEAL region makes it difficult to interpret the data. We did not identify jaundice in the coatis of any age or park that could suggest acute hepatic injuries. Despite these gaps, we suspect a hepatic disorder in the EEAL coatis. Interestingly, we did not capture young coatis in the EEAL or detect them in a camera-trap study performed at the same time for 18 months (data not shown).

The highest plasma concentration of GGT in the PNC coatis without the simultaneous increase of AST and ALT is puzzling. It is common to find increased AST, ALT, and GGT in animals with liver disorders (GREEN; FLAMM, 2002), but the increase of only GGT can have many causes. Clinically, GGT is an auxiliary indicator for the diagnosis of 


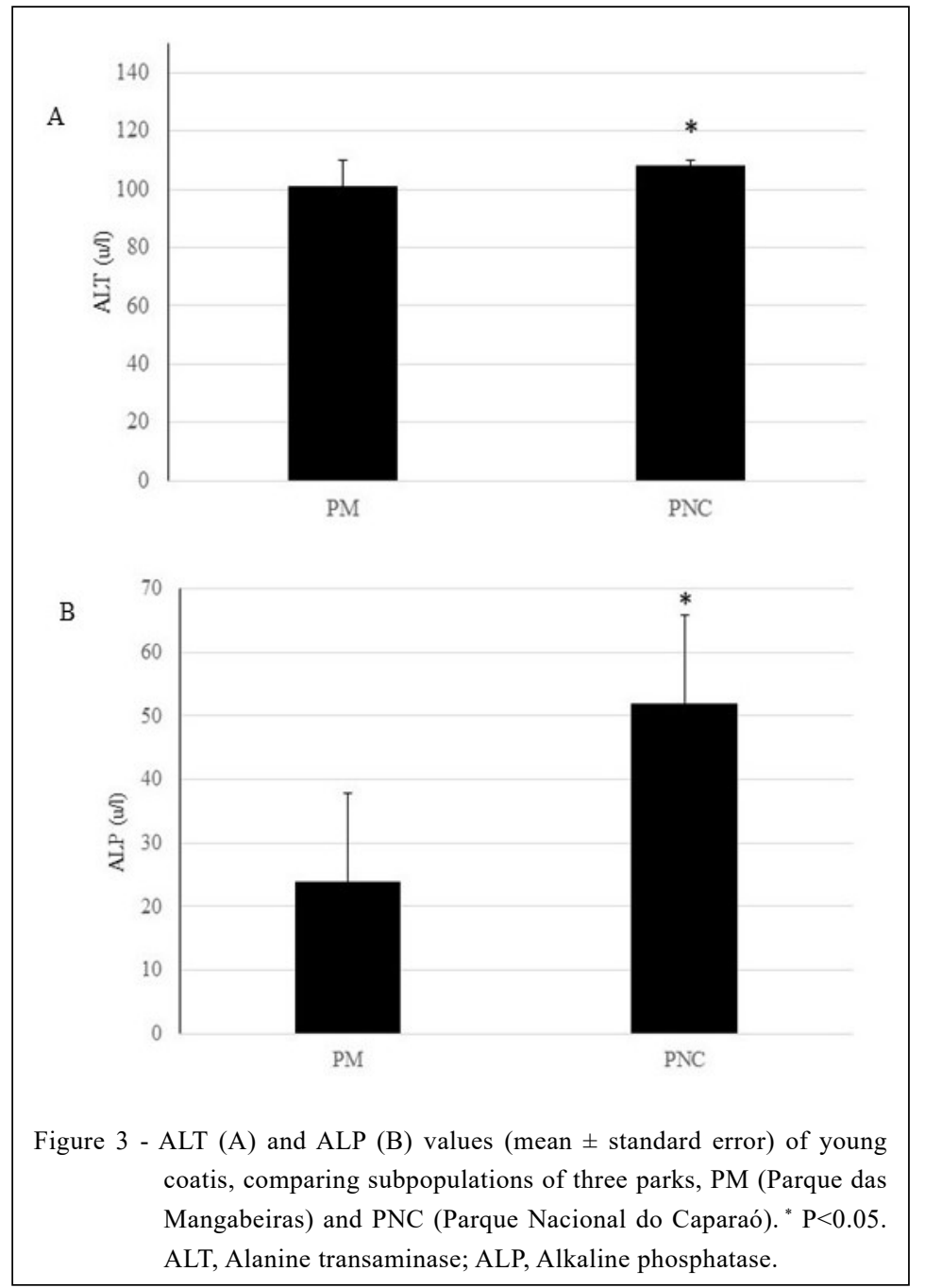

intoxications, metabolic alterations (LEE; JACOBS, 2009), kidney diseases, and liver disorders (GREEN; FLAMM, 2002). While we strongly suspect a liver disorder in the EEAL coatis, we ruled out a priori liver disorder in the PNC individuals. No other clinical signals of metabolic and kidney disorders were observed. The EEAL coatis, which do not consume food from human sources, and the adult coatis of the PM have similar levels of plasmatic GGT. Therefore, it is implausible for the consumption of the food dispensed by visitors to be linked to the higher plasma concentration of GGT in the adult coatis of the PNC.

Among all the possibilities of disorders that affect GGT, chronic intoxication seems to be most plausible. In the PNC region, there is intensive agricultural activity of Coffea arabica (OLIVEIRA et al., 2008), with the regular use of herbicides and pesticides, which were largely studied for their contribution to liver damage in mammals (BENEDETTI et al., 2004; ÇAĞLAR; KOLANKAYA, 2008]. Some studies have shown that conventional coffee crops are treated with abusive quantities of herbicides and pesticides (QUEIROZ et al., 2018).

Both the PM and the EEAL are surrounded by urbanized areas, while the PNC is predominantly surrounded by coffee plantations (OLIVEIRA et al., $2008)$. Coffee crops $(45.45 \%)$, pasture $(31.47 \%)$, and subsistence crops $(0.54 \%)$ constitute $77.46 \%$ of the area around the PNC (OLIVEIRA et al., 2008). For the region of Alto Caparaó in the western part of the PNC, 
the predominant economic activity is growing coffee, followed by tourism, and it is a part of the home range of the studied coatis. The coffee plantations, which should be distant respecting the ecological buffer zone of the PNC, are located within the PNC (OLIVEIRA et al., 2008]. This facilitates the consumption of coffee beans as well as the contamination of the animals and plants of the park, many of which are food sources for the coatis. Indeed, the coatis of this region frequently are observed feeding on ripe grains of coffee, given the proximity of the crops (W.P.L., personal observation). Therefore, we suspected that the increased plasmatic GGT in the adult coatis of the PNC is linked to cumulative and chronic intoxication.

The enzyme ALT occurs in the cytoplasm of hepatocytes, making it the best indicator for hepatic affections. Increased ALP without the other hepatic markers in young animals is suggestive of metabolic alterations of bone (SHARMA et al., 2014). However, if the ALP is accompanied by an increase of ALT, the possibility of liver damage becomes stronger (GREEN; FLAMM, 2002). Considering that the coatis of the PNC have significantly higher levels of ALT and ALP in relation to those of the $\mathrm{PM}$, it is strongly suggestive of a hepatic disorder in PNC young coatis.

Therefore, in the PNC, young coatis are affected by some kind of chronic hepatic impairment. Deteriorated foods consumed by young coatis may cause hepatic alterations, but this is unlikely as long as adults access the sources of discarded food before it is discarded, leaving little for young coatis to consume (personal observation). Therefore, we try to understand how young coatis could have liver problems.

Considering that the GGT is high only in the adult coatis of the PNC, we suspect that the young coatis are in an initial process of hepatic intoxication by substances they consume in the environment. The cumulative effect of toxins may not have been high enough to stimulate the increase in GGT due to the age of the young coatis. Indeed, the blood chemistry profile of adult coatis from PNC is highly suggestive of liver damage by toxicants, which is according with blood chemistry alterations in young ones.

Despite an apparent advantage of PM exploring human food discarded, there are many negative impacts on feeding ecology of coatis (RODRIGUES et al., 2022). Involuntary food supplementation can disrupt the food chain and the eating behavior of coatis. The proximity between visitors and coatis is a potential risk to transmission of diseases (MORAES et al., 2017) and seed dispersion of exotic botanic species in the Atlantic Forest (ALVES-COSTA; ETEROVICK, 2007).

Our study was focused in the weight and some blood chemistry markers, which we recognized as a narrow approach to a problem that seem to be much bigger than we expected. Thus, new investigation could explore the feeding ecology and other health aspects resulting of coati-human interaction to a more complete understanding about the changes we reported on coatis.

\section{CONCLUSION}

We observed a wide range of weight and blood chemistry parameters in the coatis of the three ecological parks in Minas Gerais state. Despite our study is not experimental, the results are suggestive that highest amount of visitors influences coatis weight, but not blood chemistry parameters. The wild coati's management of the three parks should include an environmental education to visitors to evict inappropriately food discard. Likewise, a clinical investigation on toxicants and pathogens in PNC and EEAL coatis, should be carry on. For now, the weight and blood chemistry data of the PM seem to be the most appropriate to serve as a physiological reference to the wild coatis.

\section{ACKNOWLEDGEMENTS}

The authors are grateful to the park staff for their logistical support. Conselho Nacional de Desenvolvimento Científico e Tecnológico $(\mathrm{CNPq})$ provided Master's scholarships for R. B. Repolês e C. S. Cesario. The translation was supported by the Graduate Program in Environmental Sciences and Technologies of the Universidade Federal do Sul da Bahia.

\section{BIOETHICS AND BIOSSECURITY COMMITTEE APPROVAL}

All procedures performed had the approval of The Ethical Animal Use Committee of the Universidade Federal de Viçosa (CEUA- UFV n ${ }^{\circ}$ 03/2013) and of Brazilian (ICMBio $\mathrm{n}^{\circ}$ 37225-2/2013) environmental agency.

\section{DECLARATION OF CONFLICT OF INTERESTS}

The authors declare that they have no known competing financial interests or personal relationships that could have appeared to influence the work reported in this paper. Therefore, the authors declare the following financial interests/personal relationships which may be considered as potential competing interests. 


\section{AUTHORS' CONTRIBUTIONS}

All authors contributed to the manuscript.

\section{REFERENCES}

ALVES-COSTA, C. P. ; ETEROVICK, P. C. Seed dispersal services by coatis (Nasua nasua, Procyonidae) and their redundancy with other frugivores in southeastern Brazil? Acta Oecologica, v.32, p.77-92, 2007. Available from: <https://www.sciencedirect.com/ science/article/abs/pii/S1146609X0700032X > . Accessed: Jan. 20, 2020. doi.org/10.1016/j.actao.2007.03.001

BENATAR, J. R. et al Effects of high and low fat dairy food on cardio-metabolic risk factors: a meta-analysis of randomized studies. PLoS ONE, v.8, n. 10, e76480. 2013. Available from: $<$ https://doi.org/10371/journal.pone.0076480>. Accessed: Jan. 28 , 2020. doi.org/10371/journal.pone.0076480.

BENEDETTI, A. L. et al. The effects of sub-chronic exposure of Wistar rats to the herbicide Glyphosate-Biocarb ${ }^{\circledR}$. Toxicology Letters, v.153, p.227-232, 2004. Available from: $<$ https://www.sciencedirect.com/science/article/abs/pii/ S0378427404002188?via\%3Dihub>. Accessed: Jan. 30, 2019. doi.org/10.1016/j.toxlet.2004.04.008.

BRADLEY, C. A.; ALTIZER, S. Urbanization and the ecology of wildlife diseases. Trends Ecology and Evolution, v.22, p. 95-102, 2006. Available from: <https://www.ncbi.nlm.nih.gov/ pmc/articles/PMC7114918/>. Accessed: Jan. 28, 2020. doi. org/10.1016/j.tree.2006.11.001.

ÇAĞLAR, S.; KOLANKAYA, D. The effect of sub-acute and sub-chronic exposure of rats to the glyphosate-based herbicide Roundup. Environmental Toxicology Pharmacology, v.25, n.1, p. 57-62, 2008. Available from: <https://www.sciencedirect.com/ science/article/pii/S1382668907001135?via\%3Dihub>. Accessed: Jan. 30, 2019. doi.org/10.1016/j.etap.2007.08.011

DIERENFELD, E. S. Captive wild animal nutrition: a historical perspective. Proceedings Nutritional Society, v.56, p. 989-999, 1997. Available from: < https://www.cambridge.org/core/journals/ proceedings-of-the-nutrition-society/article/captive-wild-animalnutrition-a-historical-perspective/8CB70B7A3643C3AB95E A17197C575239>. Accessed: Jan. 20, 2020. doi.org/10.1079/ PNS19970104.

FERREIRA, G. A. et al. Diet of the coati Nasua nasua (Carnivora: Procyonidae) in an area of woodland inserted in an urban environment in Brazil. Revista Chilena de Historia Natural, v.86, p.95-102, 2013. Available from: <https://scielo.conicyt.cl/ scielo.php?script $=$ sci abstract\&pid $=$ S0716-078X20130001000 08\&lng=pt\&nrm=iso\&tlng=en $>$. Accessed: Dec. 11, 2019. doi. org/10.4067/S0716-078X2013000100008.

GREEN, R.M.;FLAMM, S.AGA technical review on the evaluation of liver chemistry tests. Gastroenterology, v.123, n.4, p.1367-1384, 2002. Available from: <https://www.sciencedirect.com/science/ article/pii/S001650850200241X?casa token=-C69G1JHXr4AAA AA:gjFC7L3ua9sHVXpVM7Sj01_mFxYnYom1ylPTB6oRNQr-Bw4bOu q0qEg8 snUOraUOKFOrlSGEu>. Accessed: Jan. 28, 2020. doi.org/10.1053/gast.2002.36061.

IEF. Parques de Minas. Available from: <http://www.ief.mg.gov.br/ unidades-de-conservacao/parques-de-minas $>$. Accessed: Apr. 01, 2020.
JOHNSEN, S. H. et al. Elevated high-density lipoprotein cholesterol levels are protective against plaque progression a follow-up study of 1952 persons with carotid atherosclerosis the Tromsø study. Circulation, v.112, p.498-504, 2005. Available from: <https://www.ahajournals.org/doi/full/10.1161/ circulationaha.104.522706>. Accessed: Jan. 20, 2020. doi. org/10.1161/CIRCULATIONAHA.104.522706.

LEE, D.; JACOBS Jr, D. R. Is serum gamma-glutamyltransferase a markes of exposure to various environmental pollutants? Free Radical Research, v.43, n.6, p.533-537, 2009. Available from: $<$ https://pubmed.ncbi.nlm.nih.gov/19370474/>. Accessed: May. 30, 2020. doi.org/10.1080/10715760902893324.

LOUZADA, M. L. C. et al. Ultra-processed foods and nutritional profile of the diet in Brazil (2008-2009). Revista de Saúde Pública, v.49, p.38-49, 2015. Available from: <https://www. scielo.br/scielo.php?pid=s0034-89102015000100227\&script=sci arttext>. Accessed: Dec. 11, 2019. doi.org/10.1590/S00348910.2015049006132 .

MACHADO, F. C.; SOUZA, F. A. Aspectos socioambientais da Estação Ecológica Água Limpa e seu entorno, Cataguases - MG. [Monograph], Faculdade de Ciências Biológicas, Faculdades Integradas de Cataguases, Minas Gerais, Brazil. 2008. Accessed: Jun. 10, 2015.

MACHOVSKY-CAPUSKA, G. E. A nutritional perspective on plastic ingestion in wildlife. Science of Total Environment, v.656, p.789-796, 2019. Available from: <https:/www.sciencedirect. com/science/article/abs/pii/S0048969718347739>. Accessed: May. 22, 2020. doi.org/10.1016/j.scitotenv.2018.11.418.

MARÉCHAL, L. et al. Assessing the effects of tourist provisioning on the health of wild Barbary Macaques in Morocco. PLoS ONE, v.11, n. 5: e0155920, 2016. Available from: $<$ https://journals.plos.org/ plosone/article/figure?id=10.1371/journal.pone.0155920.g005>. Accessed: Jan. 20, 2020. doi.org/10.1371/journal.pone.0155920.

MORAES, M. F. D. et al. Filarial nematodes with zoonotic potential in ring-tailed coatis (Nasua nasua Linnaeus, 1766, Carnivora: Procyonidae) and domestic dogs from Iguaçu National Park, Brazil. Veterinary Parasitology: Regional Studies and Reports, v. 8, p.1-9, 2017. Available from: <https://repositorio.unesp.br/ handle/11449/178920> <http://hdl.handle.net/11449/178920>. Accessed: Jan. 30, 2019. doi.org/ 10.1016/j.vprsr.2017.01.003.

MURRAY, M. H. et al. Wildlife health and supplemental feeding: A review and management recommendations. Biological Conservation, v. 204 (B), p.163-17. 2016. Available from: <http:// dx.doi.org/10.1016/j.biocon.2016.10.034>. Accessed: Mar. 18, 2020. doi: 10.1016/j.biocon.2016.10.034.

NABI G, (2017) Hematologic and biochemical differences between two free ranging Yangtze finless porpoise populations: The implications of habi-tat. PLoS ONE v.12(n.11): e0188570. Available from: <https://journals.plos.org/plosone/ article?id=10.1371/journal.pone.0188570 >. Accessed: Mar. 18, 2020. < https://doi.org/10.1371/journal.pone.0188570>

NEWSOME, D.; RODGER, K. Feeding of wildlife: an acceptable practice in ecotourism? In: BALLANTYNE, R. ; PACKER, J., eds. International Handbook on Ecotourism, Edward Elgar Publishing limited, UK; 2013. 520 p.

OLIVEIRA, F. et al. Identificação de conflito de uso da terra em áreas de preservação permanente no entorno do parque nacional

Ciência Rural, v.52, n.6, 2022. 
do Caparaó, Estado de Minas Gerais. Revista Árvore, v.32, n.5, p.899-908, 2008. Available from: <https://www.scielo. br/scielo.php?pid=S0100-67622008000500015\&script $=$ sci abstract\&tlng $=\mathrm{pt}>$. Accessed: Jan. 30, 2019. doi.org/10.1590/ S0100-67622008000500015.

ORAMS, M. B. Feeding wildlife as a tourism attraction: a review of issues and impacts. Tourism Management, v.23, p. 281-293. 2002. Available from: <https://www.sciencedirect.com/science/ article/abs/pii/S0261517701000802>. Accessed: Jan. 20, 2020. doi.org/10.1016/S0261-5177(01)00080-2.

QUEIROZ, V. T. et al. Environmental risk assessment for sustainable pesticide use in coffee production. Journal Contaminant Hydrology. 18-27. 2018. Available from: $<$ https:// www.sciencedirect.com/science/article/pii/S0169772217303121>. Accessed: Jan. 30, 2019. doi:10.1016/j.jconhyd.2018.08.008.

RIEKEHR, Jr L. E., et al, Parâmetros comparativos de indicadores bioquímicos plasmáticos de duas populações de quatis (Nasua nasua - LINNAEUS, 1766) com e sem ação antrópica. Arquivos Brasileiros de Medicina Veterinária e Zootecnia, v.69, n.3, p.659-666, 2017. Available from: <https://www.scielo. br/scielo.php?pid=S0102-09352017000300659\&script $=$ sci abstract\&tlng=pt $>$. Accessed: Jan. 28, $2020 . \quad<$ https://doi. org/10.1590/1678-4162-9110>.

ROCHA, E. A.; ABJAUD, T. T. A metropolização de Belo Horizonte e sua relação com as áreas verdes e o turismo: Parque da Mangabeiras vs. Praça Sete. Observatório Inovação Turismo, v.7, n.3, p. 63-85, 2012. Available from: <http://bibliotecadigital. fgv.br/ojs/index.php/oit/article/view/7874>. Accessed: Apr. 01, 2020. doi.org/10.12660/oit.v7n3.7874.

RODRIGUES, D. H. D., et al. Feeding ecology of wild brownnosed coatis and garbage exploration: A study in two ecological parks. Animals, 11, 2412, 2021. <https://doi.org/10.3390/ ani11082412>. Available from: <https://www.mdpi.com/20762615/11/8/2412>. Accessed: Sep. 01. 2021.

RODRIGUES, D. H. D., et al. Potentially harmful materials in the feces of wildring-tailed coatis(Nasuanasua) and health implications. Ciência Rural, v.52, n.2, e20210108, 2022. Available from: $<$ https://www.scielo.br/j/cr/a/VMtpXb6CFchw8pqnV7Yvz6J/>. Accessed: Sep. 01, 2021.

RODRIGUES, R. R. et al. Determinação de hemograma, bioquímica sérica e pesquisa de hemoparasitas em quatis
(Nasua nasua) em condições de cativeiro no estado do Rio de Janeiro. Revista Brasileira de Ciências Veterinárias, v.3, n.3, p. 89-92, 1996. Available from: <https://pesquisa.bvsalud.org/ portal/resource/pt/vti-712867>. Accessed: Dec. 20, 2016. doi. org/10.4322/rbcv.2015.054.

SATO, A.; et al. Effects of Age and Sex on Hematologic and Serum Biochemical Values of Vervet Monkeys (Chlorocebus aethiops sabaeus). Journal of the American Association for Laboratory Animal Science, Volume 44, Number 1, January 2005, pp. 29-34(6). Available from: <https://pubmed.ncbi.nlm. nih.gov/15697196/>. Accessed: Dec. 20, 2016. PMID: 15697196.

SEMENIUK, C. A. D. et al. Using fatty-acid profile analysis as an ecologic indicator in the management of tourist impacts on marine wildlife: a case of stingray-feeding in the Caribbean. Environmental Management, v.40, n.10, p. 665-677, 2007. Available from: $<$ https://www.researchgate.net/publication/6200586_Using Fatty-Acid_Profile_Analysis_as_an_Ecologic_Indicator_in_the_ Management of Tourist Impacts on Marine Wildlife A Case of_Stingray-Feeding_in_the_Carib̄bean>. Accessed: ${ }^{-}{ }^{-}{ }^{-}$. .28 , 2020. doi.org/10.1007/s00267-006-0321-8.

SIEGEL, A.; WALTON, R. M. Hematology and blood chemistry of small mammals. Ferrets, Rabbits, and Rodents. Elsevier Public Health Emergency Collection, p.569-582, 2020. Available from: $<$ https://www.ncbi.nlm.nih.gov/pmc/articles/PMC7258700/>. Accessed: May. 30, 2020. doi.org/10.1016/B978-0-323-484350.00039-3.

SHARMA, U. et al. Alkaline phosphatase: An overview. Indian Journal Clinical Biochemistry, v.29, p.269-278, 2014. Available from: <https://link.springer.com/article/10.1007/ s12291-013-0408-y>. Accessed: Jan. 30, 2019. doi.org/10.1007/ s12291-013-0408-y.

XIE, L, et al. (2013) Age- and Sex-Based Hematological and Biochemical Parameters for Macaca fascicularis. PLoS ONE v.8(n.6): e64892. Available from: <https://journals.plos.org/plosone/ article?id=10.1371/journal.pone.0064892>. Accessed: Jan. 30, 2019. <https://doi.org/10.1371/journal.pone.0064892>.

WHILDE, J., et al. (2017) Precision wildlife medicine: Applications of the human-cen $\neg$ tred precision medicine revolution to species conservation. Glob. Change Biol., v.23(n.5): p.1792-1805. Available from: <https://pubmed.ncbi. nlm.nih.gov/27809394/>. Accessed: Jan. 30, 2019. <https://doi. org/10.1111/gcb.13548>. 